The Council of the Royal Society has awarded the John Murray Travelling Studentships for 1969 to Dr D. H. Lewis, University of Sheffield, to enable him to carry out research on the physiology of symbiotic algae of reef building corals at the University College of the West Indies, Jamaica; and to Dr I. Morris, University College London, to enable him to carry out research on the enzymology of photosynthesis and nitrate assimilation in phytoplankton at Nova University, Florida, and Woods Hole Oceanographic Institution, Massachusetts, USA.

The Marine Technology Society's Award for Ocean Science and Engineering has been awarded to Dr W. H. Munk and Mr F. E. Snodgrass, both of the Scripps Institution of Oceanography and the University of California's Institute of Geophysics and Planetary Physics, in recognition of their contributions to the theories and study of deep-ocean circulation and deepocean tides and for their work on sophisticated instrumentation designed for sea-bed recording and monitoring of minute fluctuations in sea environmental parameters.

The Radiation Research Society Research Award has been awarded to Dr Gerald E. Adams, Mount Vernon Hospital, Middlesex, in recognition of his research in pulse radiolysis as applied to both chemistry and biology.

All teachers of cell biology courses are reminded that the British Society for Cell Biology is anxious to have information from them about cell biology teaching, in particular an indication of how many lectures and at what level such teaching is aimed. Brief titles would be a great help. Any who employ cell biologists are invited to comment on the availability and training of cell biologists. Please scnd information to Dr L. G. E. Bell, Department of Zoology, The University, Southampton S09 5NH.

Erratum. In the article "Sequential Synthesis of Messenger RNA and Antibodies in Rabbit Lymph Nodes" by Ernst Kuechler and Alexander Rich (Nature, 222, 544; 1969), the following corrections are necessary: p. 547, column 2, line 16 should read: "The gentle method of preparing lymph node cytoplasmic extract disrupts approximately 90 per cent of the plasma cells ${ }^{14}$. Thus we estimate a total of $90 \mathrm{mg}$ of gamma globulin synthesized by the two popliteal lymph nodes or approximately 20-25 per cent of the total gamma globulin synthesized by the rabbit in response to the injection of bovine albumin."

Erratum. In the article "Peptide Chain Elongation: GTP Cleavage catalysed by Factors binding AminoacylTransfer RNA to the Ribosome" by Y. Ono, A. Skoultehi, J. Waterson and P. Lengyel (Nature, 222, 645; 1969), read as follows: (1) page 645 , paragraph 4 , ". . . tables and figures: ribosomes, $14.4 A_{260} \mathrm{~m} \mu$ units; poly $\mathrm{U}$, $50 \mu \mathrm{g} ;$ poly $\mathrm{A}, 50 \mu \mathrm{g} ; \mathrm{S}_{1}, 8.5 \mu \mathrm{g} ; \mathrm{S}_{3}, 7.9 \mu \mathrm{g} ;{ }^{14} \mathrm{C}$-phe-

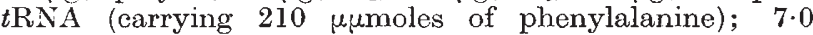
$A_{260 \mathrm{~m} \mu}$ units; ${ }^{14} \mathrm{C}$-lys- $t \mathrm{RNA}$ (carrying $235 \mu \mu$ moles of lysine); $8.2 A_{260 \mathrm{~m} \mu}$ units; discharged $t$ RNA, $37 A_{260 \mathrm{~m}} \mu$ units." (2) Page 647, section on GTP cleavage catalysed by $S_{1}, S_{3}$ and by $S_{2}$, line $3:$ ". . are not the result of . . ". Erratum. In the article by J. W. Hastings, G. Mitchell, P. H. Mattingly, J. R. Blinks and M. van Leeuwen, "Response of Aequorin Bioluminescence to Rapid Changes in Calcium Concentration" (Nature, 222, 1047; 1969), the legend to Fig. I should contain the following insertion after the word "between" in line 10: " $\mathrm{M}_{1}$ and $\mathrm{P}_{1}$; about $25 \mathrm{~ms}$ between $\mathrm{M}_{1}$ and $\mathrm{M}_{2}$, and about $7 \mathrm{~ms}$ between $\mathrm{M}_{2}$ and $\mathrm{P}_{2}$ ". At the end of paragraph 4, add: "For calculation of $\mathrm{Ca}^{2+}$ in the calcium buffer system, the apparent association constant for the binding of calcium to EGTA was taken to be $5 \times 10^{5} \mathbf{M}^{-1}$ (Ebashi, S., and Endo, M., Progr. Biophys. Mol. Biol., 18, 123; 1968)." In paragraph 7 , line $14,2 \times 10^{-7}$ should read $2 \times 10^{-6}$. In the legend to Fig. 3, lino 9, (S) should read $(R-S)$ and $(R)$ should read $(\mathrm{R}-\mathrm{R})$.

\section{International Meetings}

August 18-23, Physiology of Digestion and Metabolism in the Ruminant, Cambridge (Third International Symposium, PO Box 10, Cambridge, UK).

September 11-12, Structure and Function of Interphase Ghromosomes (British Society for Cell Biology), Glasgow (Dr John Paul, Beatson Institute for Cancer Research, Royal Beatson Memorial Hospital, 132 Hill Street, Glasgow C3, UK).

October 7-9, Illumination, Strasbourg (A. Vallat, Association Francaise de L'Eclairage, International Commission on Illumination, 52 Boulevard Malesherbes, Paris 8, France).

October 7-10, Tsunamis and Tsunami Research, Hawaii (Dr W. M. Adams, Secretary, Tsunami Committee, International Union of Geodesy and Geophysics, c/o Institute of Geophysics, University of Hawaii, 2525 Correa Road, Honolulu, Hawaii).

October 1I-18, 57th Annual Meeting of International Dental Federation, New York (G. H. Leatherman, Secretary-General, 64 Wimpole Street, London W1).

October 13-15, 3rd Annual Conference of International Iron and Steel Institute, Japan (The Iron and Steel Institute of Japan, 1-5 Otemachi, Chiyoda-ku, Tokyo, Japan).

October 13-17, Clean Air Congress and Exhibition, Dusseldorf (Verein Deutscher Ingenieure, Postfach 1139, 4 Dusseldorf 1, Germany).

October 14-16, Electronic Packaging and Production, Brighton, UK (M. S. Kiver, President, Electronic Packag. ing and Production, $222 \mathrm{~W}$ Adams Street, Chicago, Ill., 60606, USA).

October 14-22, 11th Congress of Pan-Pacific Surgical Association, Honolulu (Dr F. J. Pinkerton, 236 Alexander Young Building, Honolulu, Hawaii 96813).

\section{Sabbatical Itinerants}

In the hope of providing some practical assistance in the good cause of mobility between laboratories, Nature advertises the needs for housing of families about to take up periods of sabbatical leave. To begin with, no charge will be made for advertisements like this. It is hoped that a period of experiment will show what form these advertisements could most usefully take and whether they are effective.

Wanted: Furnished flat with 1 large or 2 average rooms, bath, kitchen and central heating, convenient for Royal Veterinary College, Royal College Street, London NW 1, from July 22 for 1 year at least. Please contact Professor Hancock, Depart. ment of Veterinary Anatomy, Royal Veterinary College, London NWl.

Wanted: Furnished 3 or 4 bedroom house in Man. chester, convenient for UMIST, from September 1969 for approximately I year. Please contact Dr A. G. Freeman, Chemistry Department, Victoria University of Wellington, PO Box 196, Wellington, New Zealand.

Vacant: From September for 6 months or longer, fully furnished Regency house, Keats Grove, Hamp. stead, London. 3-4 bedrooms, 3 recoption rooms, study, garden, full central heating. Close Heath, excellent communications central London $(25 \mathrm{~min}$, bus to Bloomsbury). Write Mrs E. Carter, Upper Kilcott, Hillesley, Wotton under Edge, Gloucestershire. 